\title{
Review of Omani Aflaj Systems: an Element of National Water Resources, Technology and Economic Developments
}

\begin{abstract}
Abulbasher M. Shahalam
Department of Civil Engineering, College of Engineering, Sultan Qaboos

University, P. O. Box 33, Al Khod 123, Muscat, Sultanate of Oman.

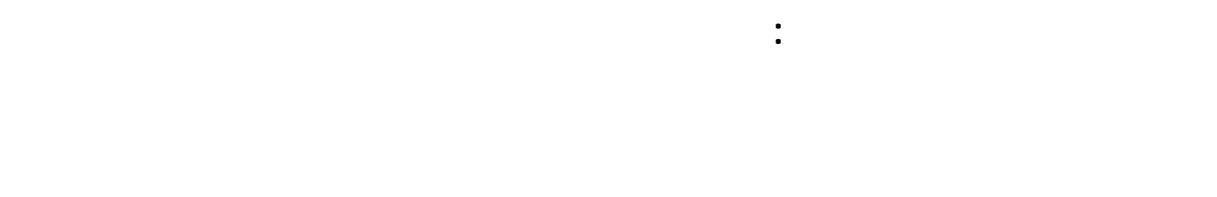

خلاص هة : يتض من البهث لستعراضأشلملاً للاوجه المختلفه للأفلاج فيسطنة عملن ومنها الزراعة والتربة ومصادر الميله

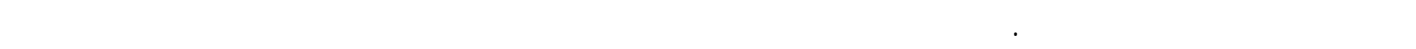

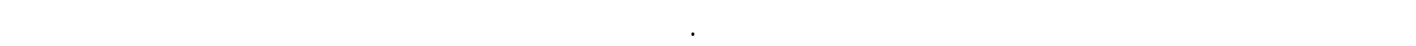

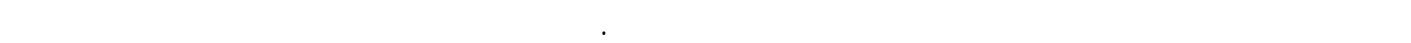

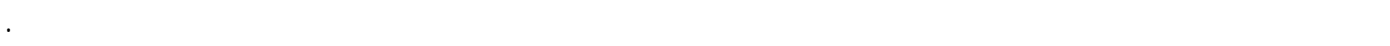

ABSTRACT: The paper includes a comprehensive review of the various aspects: agriculture, soil, water resources and socio-economic concerns associated with the aflaj facilities within the Sultanate of Oman. From available literature, the author identified and presented factors that affect the viability and sustainance of this traditional, existing and unique system of water resources management. The system weakness and strength at the advent of modern technology, life-style and wealth were also identified. Technical data on demography, geography, soil, water, irrigation, croppattern and activities of organizations related to aflaj systems were summerized and illustrated in figures and tables.
\end{abstract}

\section{Introduction}

The Sultanate of Oman is located at the Southeast corner of the Arabian Peninsula and has an area of about 309500 sq. $\mathrm{km}$. It is within the geographic block lying between Latitudes $16^{\circ} 40^{\prime} \mathrm{N}$ and $27^{\circ} 20^{\prime} \mathrm{N}$ and Longitudes $51^{\circ} 50^{\prime} \mathrm{E}$ and $59^{\circ} 40^{\prime} \mathrm{E}$. The coastline of the country extends about 1700 $\mathrm{km}$ from the Strait of Hormuz in the North to the border of the Republic of Yemen in the South. The climate of the country is hot and humid in summer (June $31-45^{\circ} \mathrm{C}$ ) and moderate in winter (January $20-25^{\circ} \mathrm{C}$ ). The country experiences an average rainfall of $100 \mathrm{~mm}$ over the entire area with extremes of $300 \mathrm{~mm}$ over northern mountain regions and $55 \mathrm{~mm}$ over the central part of Oman. The total population of the country is about 2.3 million of which nearly $74 \%$ are native Omanis (MNE, 1999). Most of the population is concentrated in the coastal plains, which represent nearly $3 \%$ of the total land area.

The country has very distinct topographical features consisting of wadis, plains and mountains. There are three main mountain ranges in the country, and all of them are along the coastline and separate the near-sea coastal plain from the interior sandy dry lands. The mountain ranges are at north (Mosandom, Al Hazar Al-Gharbi, and Al Jabal Al-Akhdar), South (Al-Dhofar) and mid-coastline (Al-Huq). Mountains occupy nearly $15 \%$ of the country. About $82 \%$ of the country is mainly sand and gravel desert and is part of the larger Arabian desert known as the Empty Quarter, Rub Al-Khali (Ministry of Information, MI, 1997). 


\section{SHAHALAM}

The Sultanate of Oman has two main sources of water: traditional groundwater and nontraditional water produced from high-tech desalination plants and treated wastewater effluent. Traditional groundwater sources may be separated into two groups: mostly confined fossil water (Brackish/saline) in the central and southwest deserts and unconfined acquifers and fractured rock containment in the mountains and mountain plains (Al-Harthy et al., 1999; Bernett, 1994; CORD, 1992; GIBB et al., 1975; Kew, 1995; Lenton, 1995; Ministry of Agriculture and Fishery, MAF, 1989; MI, 1995; Ministry of Water Resources, MWR, 1991; 1992a; 1992b; 1994a; 1995; PDO, 1988). The latter type of ground-storage is mainly fed by rainfall in the mountain ridges in the north and south of the country.

The non-traditional water is produced in desalination processes, which accounts for nearly 3 million gallons per day i.e. $163000 \mathrm{~m} 3$ /day (Al-Kalbani, 1993). The unconfined acquifers and fractured rock containment in many places crop-up on the surface as springs and wadi flows under artesian pressure. There are many shallow unconfined acquifers in the northern plains, that harbor water within a depth range of 7 to $15 \mathrm{~m}$. This water is exploitable with even hand-dug wells.

The natural water sources are the nuclei of oasis and community centers. Water abstraction processes along with associated surface and/or underground channels that convey water to the community for domestic and irrigation needs are known locally as "falaj" with plural "aflaj" (MWR, 1995). In the past, the village communities, and their social structure and economy would largely depend on physical characteristics of the water source. The community size and livelihood of people depended on the quantity of natural water flow.

In more recent times, particularly with the new oil wealth, some important changes in the features of national economy, education and life style have taken place. Available technology and the new source of livelihood had a profound effect on the traditional way of life in the falaj community. Public and private sectors in the country invested efforts and resources for extensive study programs to delineate the underground water resources and policies that may lead to planning towards optimal utilization of the resources. Controlled recharge systems are developed to capture and retain scarce rainwater in the aquifer systems. Diesel and electric pumps are introduced to raise relatively large volumes of water for agricultural and other purposes. Consequently traditional groundwater systems are affected. In addition, modern mobility, job opportunity outside of old communities and the economy have elevated the people's aspiration for better life. The trend caused immense stress on the traditional falaj communities. The falaj systems in the country, however, retain a substantial stake in the country's water resources. More than 3000 aflaj support 35\% of irrigated area and consume nearly $33 \%$ of national water demand (MWR,1995). The aflaj systems and associated communities badly need adequate attention and readjustment within the new environment for survival.

During the past two decades, numerous articles and study reports directly or indirectly related to aflaj systems in Oman were published. A collective reference to this information, however, is missing. This paper reviews available literature on subjects that affect various aspects of aflaj systems in Oman, particularly present status of aflaj systems under the influence of modern economy, education, resource orientation and adaptation to technology. The impacts of new discovery of water and the introduction of new technologies in the augmentation of water sources and application of irrigation water are presented in the context of existing aflaj systems.

\section{Aflaj Types}

The geomorphology of the Sultanate of Oman indicates that the region experienced surface water flow in prehistoric periods and had gradually been turned into a drier climate through time. Consequently the inhabitants abandoned surface irrigation and developed innovative techniques of capturing, storing and conveying water from underground sources. Most of their scanty waters originated from mountain rainfalls infiltrated into the ground and rock fractures (Wilkinson, 1983). Normal evapotranspiration rate in the region is above $3000 \mathrm{~mm} / \mathrm{yr}$., which is about 30 times the 


\section{REVIEW OF OMANI AFLAJ SYSTEMS}

average rainfall (Siddeek, 1992). Consequently surface water in the country is insignificant. Surface runoff generated from burst of occasional rainfall persists on surface for a very short time. Due to the scarcity of water, the population grew in areas where groundwater sources were reachable (MWR, 1995; Wilkinson, 1977; Wilkinson, 1983).

Afalaj supplies water to its community, not to an individual. Based on collective responsibility within the community, the intricate and complex systems for sharing responsibilities and for maintaining and distributing water grew through generations. These specific aspects of falaj systems are topics of extensive studies by many organizations, particularly by agencies associated with water resources. Any future policy of water resources in the country has to carefully take into consideration the intricate and delicate issues of collectiveness in ownership and responsibility of maintaining the falaj systems.

Nearly 3000-4000 aflaj systems are estimated to be in existence in Oman (MI, 1997; MWR, 1995). They supply nearly $33 \%$ of the nation's domestic water. More than $50 \%$ of the nation's population lives in small urban and rural areas and they are dependent on groundwater sources (combined wells and aflaj systems). Based on physical features of groundwater sources, the aflaj systems are divided into three discrete groups: Dawudi, Ghayli and Ayni Falaj.

\subsection{Dawudi Falaj}

In this system (Figure 1a), a mother well is constructed to a depth below the groundwater level in the acquifer. From the mother well, tunnels are constructed to convey water to the surface and subsequent transport to the point of claims and uses. The flows are mainly dependent on artesian pressure in the acquifer and flows by gravity. Once the system is in place, the flow is natural and it does not need any direct input of external energy.

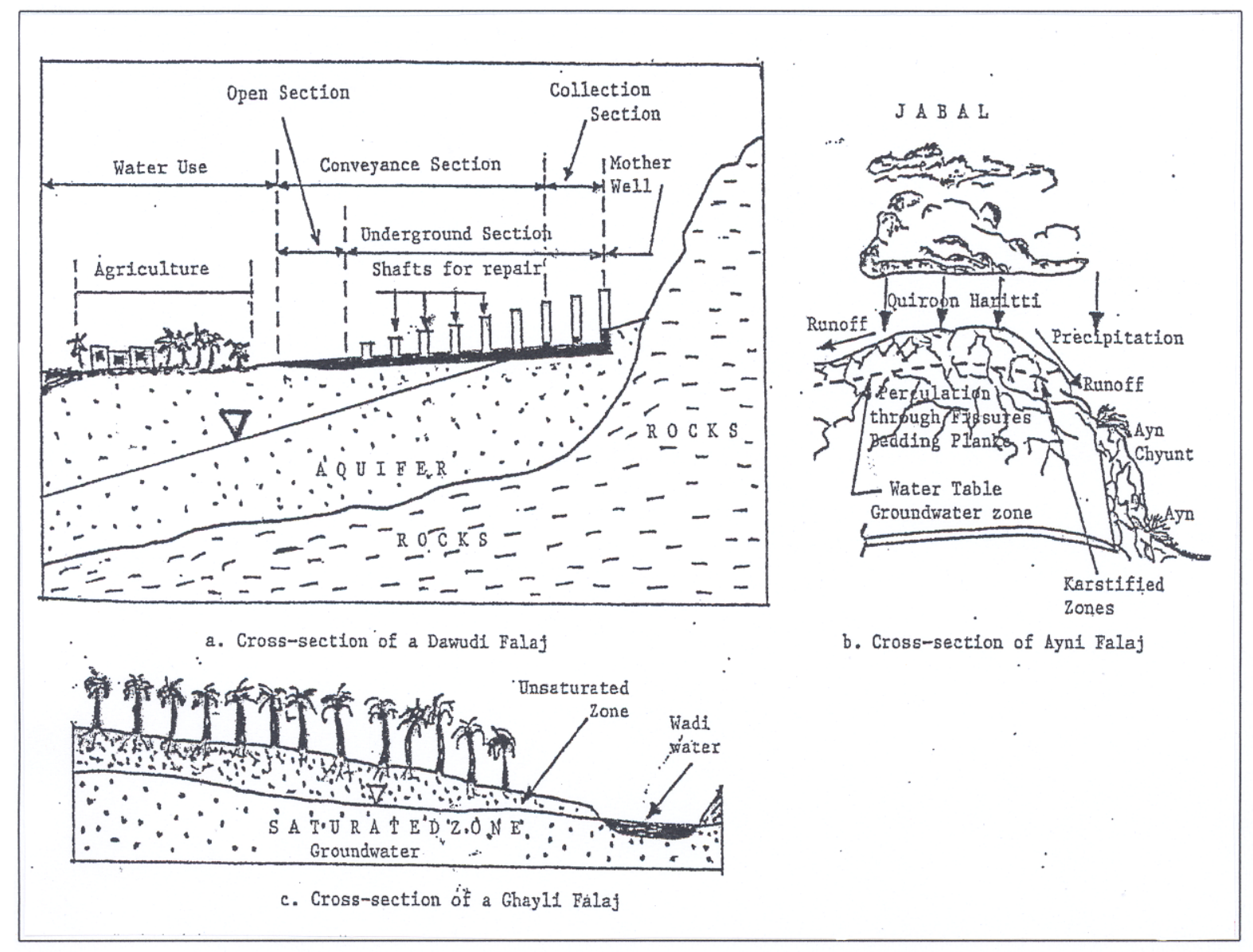

Figure 1. Cross-section of different falaj systems 


\subsection{Ghayli Falaj}

In Ghayli type of Falaj (Figure 1c), groundwater crops-up on the surface in wadi beds as base flow of the wadi (valley). Water is captured in depressions and channeled to the point of use.

\subsection{Ayni Falaj}

Hydraulic structures in Ayni (spring) Falaj (Figure 1b) are directly fed from springs. Many of such springs are hot. An example of such a system can be found at Ayn-Hammam-Al-Ali on the Bawshar spring-line near Muscat. Most of these springs rise from limestone in the mountain ranges.

\section{Principle Locations of Falaj Systems}

Northeastern Mountain terrain and Wadis are the main sites for falaj. These include areas of Al-Batinah, Adh-Dhahirah, Ad-Dakhliyah, Ash-Sharqiyah and the region of Madha (Figure 2), (AlKalbani, 1993; Dutton, 1985; Dutton, 1995; MWR, 1994b; MWR, 1995; Mott-McDonald, 1994c, 1989; Trow, 1986; Travers, 1993.

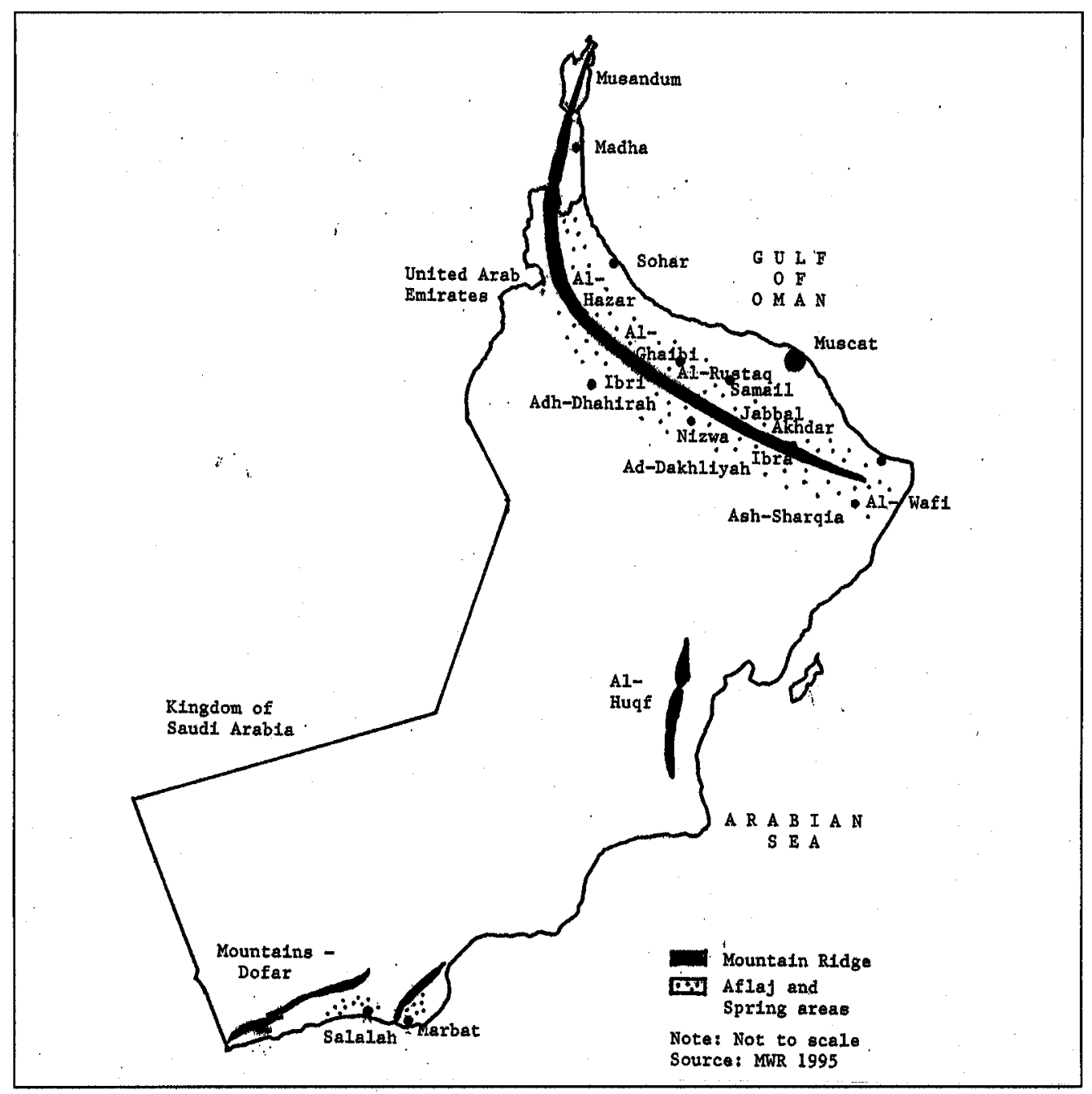

Figure 2. Main area of aflaj, wells and springs in the sultanate of Oman

The hydraulic flow monitoring program initiated by the Ministry of Water Resources (MWR) selected several areas. The number of flow monitoring stations in these programs (Table 1) 


\section{REVIEW OF OMANI AFLAJ SYSTEMS}

indicates roughly the relative distributions of afalaj by area. The principal locations of spring based falaj systems (MWR, 1995) appeared in Table 2.

Table 1: Ministry of water resources flow monitoring stations in aflaj systems (as of January 1995)

\begin{tabular}{|l|c|}
\hline Region & Number of Monitoring Stations \\
\hline Muscat & 28 \\
\hline Al-Batinah & 101 \\
\hline Al-Dhahirah & 69 \\
\hline Al-Dhakhilia & 96 \\
\hline Al-Sharqiyah & 211 \\
\hline Dhofar & 20 \\
\hline
\end{tabular}

Table 2: Main locations of spring based falaj systems

\begin{tabular}{|c|l|}
\hline Region & \multicolumn{1}{|c|}{ Location } \\
\hline Marbat & Scarps adjacent to Southern coast in Murbat \\
\hline Salalah & Scarps adjacent to Southern coast in Salalah \\
\hline Al-Batinah & Coast and interior terrain of North-east Oman mountains \\
\hline Wadi Khabab & Northern Oman mountains \\
\hline Madha & North extension of North-east Oman Mountains \\
\hline
\end{tabular}

\section{National Growth and Water Balance}

The Sultanate of Oman is a fast developing country. Statistical data (Ministry of National Economics, MNE, 1999) indicated that nearly $25 \%$ of the population is in schools and universities. From population estimates of 1970 and census data of 1993, it appears that the population is growing at an approximate rate of 3.6\% per year (MWR, 1995). Gross national income was about US $\$ 7000$ per capita in year 1996. The income level places the country as one of the affluent countries in the world. Assuming an average 150 litre/day/person for domestic water use, total domestic water needs for 2,000,000 people is about $110 \mathrm{Mm}^{3} /$ year. Desalination processes produce about $43 \mathrm{Mm}^{3} /$ year (MI, 1997). The difference of $67 \mathrm{Mm}^{3} /$ year is expected to be supplied from falaj and well systems tapped in groundwater sources. According to 1993/94 statistics, about 55000 hectares (MWR, 1995) of land are under cultivation. To sustain minimum irrigation, the land may need nearly $1200 \mathrm{Mm}^{3}$ /year (vegetables 413, field crop and fodders 189 and fruit trees 534 $\mathrm{Mm}^{3} /$ year). The amount was derived assuming a land distribution for crops as: $50 \%$ vegetables, $22 \%$ field crops/fodders and $27 \%$ fruit trees. It was further assumed that vegetables and fodders are irrigated for five months in a year while the fruit trees need irrigation throughout the year at a common rate of $3000 \mathrm{~m} 3 / \mathrm{month} /$ hectare (MWR, 1995). If one assumes that $50 \%$ of the total domestic water supply is reclaimed for garden and fodder irrigation, the reclaimed water supply amounts to $55 \mathrm{Mm}^{3} /$ year, which is insignificant compared to the total irrigation need. The bulk of the irrigation water has to come from groundwater.

At an average rainfall of $100 \mathrm{~mm}$ over the whole country, the total rainwater is about 31000 $\mathrm{Mm}^{3} /$ year. The country needs to capture at least $10 \%$ of this water for a sustainable water balance. This is a formidable task. The sultanate of Oman undertook some highly ambitious projects towards this goal. These projects include series of recharge dams, which impound rainwater upstream dams. Water infiltrates into the ground and augments groundwater storage. Consequently the groundwater level rises. Under the influence of such recharge efforts, many traditional afalaj wells abandoned for 


\section{SHAHALAM}

shortage of water started reviving with a substantial production capacity. The reviving of old afalaj systems, however, needs renovation and modern management techniques integrated into the community framework for proper functioning.

\section{Review of Some Selected Study Reports}

\subsection{Studies}

The sultanate of Oman directed during the past two decades quite a number of studies towards collecting essential basic data on the nation's water resources, soils and agricultural practices. It is understood that all of these sectors are important elements in the nation's traditional falaj systems. The end objective of such information gathering is to work towards developing an optimal waterresources management policy. Consequently the consideration of falaj systems remain of paramount importance in the process as the physical systems of aflaj affects water resources. Aflaj communities remain integral parts of the nation's social structure, and their agricultural activities contribute directly to the nation's food production and economy. The following is a review of some of the important information gathered from recent study reports and published literature on falaj physical systems, soil characteristics of surrounding land and practices in irrigation and agriculture.

\subsection{Aflaj Systems}

The references Al-Kalbani, (1993), Dutton, (1995), MWR, (1991, 1995), and Wilkinson, (1983) presented the basic aspects of aflaj systems in the Sultanate of Oman. In particular AlKalbani (1993) described the existing management processes of aflaj and identified areas where improvements may be attainable. Based on collected operational data from an associated study, the paper presented a scheme for future aflaj management in the country.

Dutton $(1985,1995)$ in his articles on aflaj systems in Oman delineated the physical systems of aflaj and background history of aflaj developments. He discussed in depth the origin of aflaj systems with respect to their complex relationships with water resources, community, society, economy and agriculture. The articles identified those factors that are likely to be affected by the modern technological revolution. The author presented the weaknesses and strengths of aflaj systems and their communities. He discussed the essential elements which are required to optimize the benefits of the aflaj systems and pointed out various roles that Public Authorities such as the Ministry of Water Resources might play towards improving the systems contributing efficiently to the greater process of National well-being. The author elaborately outlined the elements of reactive and proactive management policies that could be adopted in the management of aflaj systems. The reactive group includes issues such as: (i) responding to daily queries about well permits, (ii) responding to daily queries about falaj extension, (iii) mediating in disputes among aflaj users, (iv) responding to queries about mother well protection, problem and crisis. The proactive activities involve well planned steps undertaken for solution and reduction of future problems related to inappropriate usages, unbalanced usages, non-equitable usages, inefficient usages and nonproductive usages. In conclusion, the author stressed that if an effective connection could be made among the traditional falaj water delivery systems, modern irrigation systems and appropriate management policies, beneficial aspects of falaj systems will be more appreciated. In this respect, the author cited the encouraging results obtained in an experimental station in the village of Halban in Oman. He suggested the preparation of a comprehensive database of the falaj systems that could effectively help guide future management of the systems.

The Ministry of Water Resources, Sultanate of Oman, published an information bulletin on the nation's water resources (MWR, 1991; MWR, 1995). The publications contained summaries of water resources in the country as of years 1991 and 1995 respectively. The latter contained the latest detailed information about the types and extent of falaj systems. The principal locations of falaj systems were identified. It included summaries of major groundwater reservoirs in the country.

Several case studies were carried out to test the feasibility of introducing centrally controlled aflaj irrigation systems (Wahby, 1995), water management relationships with the efficiency of 


\section{REVIEW OF OMANI AFLAJ SYSTEMS}

water use (Norman, 1997) and the effects of surrounding well on the aflaj mother-well (State Consultative Council, SCC, 1987).

Wahby (1995) presented the experience of introducing a central control of irrigation water in a falaj system. During the study, it was observed that the traditional rational basis for water distribution to farmers on a time-sharing basis failed very often to meet the requirements for quantity in time. Budgeting water under unsteady and unreliable flow conditions resulting from the unpredictability of artesian pressure of groundwater, is not an easy task. It is subjected to the risk of breaking the contract or assurance provided to the farmers. In contrast to supplies dependent on natural time-dependent flow, the reported study experimented with a central storage facility and associated distribution systems in falaj "Keed". The study tested three irrigation systems: drip, sprinkler and bubbler. The central control system was found to be a successful means to supply water for modern irrigation methods. Irrespective of varied flow conditions in the falaj, the system could deliver and maintain a constant discharge and pressure for the operation of the irrigation system. In conclusion, however, the author of the study cautiously advised about the introduction of the idea to the farmers as it may appear as a sensitive issue of changing the traditional way of water management. Similar benefits of implementation of modern water management techniques were also observed in a separate study elsewhere (Norman, 1997).

However, in another study of a falaj "Hagur" in Walayat Al-Awabi in northern Oman, investigators found that the farmers had adequate knowledge of managing irrigation water (Wilkinson, 1983). Even using traditional surface application of irrigation water, the farmers achieved an irrigation efficiency of $84 \%$. The findings were in sharp contrast to the frequent assumptions that all surface irrigation systems incur unnecessarily high water losses. It was noted that the majority of farm workers in the study area were native Omanis who are quite familiar with the proper water uses in the falaj systems. Local laborers are expected to be more aware of the scarcity of water and thus are more careful in water uses. They are better acquainted with local irrigation factors such as time of water application and the quantity of water necessary to marginally keep the soil near to its capacity of moisture content within crop root-zone without incurring access losses.

In a separate case study, the effect of personal wells on the output of the mother-well of afalaj system was studied (SCC, 1987). Individuals tap these wells in common acquifers, as diesel and electric pumps are nowadays easily available. Modern technology and the economic conditions of the people made it easy for individuals to own their personal wells. Consequently the traditional communal responsibility for afalaj system was found to be at risk. The artesian pressure in the mother-well is very often recorded to be inadequate to provide natural flows for those who still rely on the mother-well.

A BRGM (BRGM, 1992) consulting report reviewed 12 aflaj systems in northern Oman in connection with designing an engineering maintenance program for old aflaj structures. The report presented the usual maintenance works which are needed to operate the systems with efficient flow and delivery of water.

\section{Soil and Irrigated Agriculture}

The nation's policies on soil and irrigation management are bound to have direct impact on the country's falaj systems. A number of important studies were completed to classify soils and assess the inventory of available waters across the nation. The following is a short review of information related to these sectors.

\subsection{Soil}

Various public organizations and Ministries in the Sultanate of Oman carried out studies to classify soil at the national level (Abdel-Baqui, 1995; London, 1984; MAF, 1990). London (1984) and MAF (1990) included soil types and their extents within Oman. In addition, several studies related to agriculture and water management also contained soil information for selected areas (Hundertmark, 1995; Kew, 1995; Trow, 1986). Kew (1995) reported soil characteristics in relation 


\section{SHAHALAM}

to water resources and soil moisture relationships in the central Oman areas (al-Wasta). The falaj systems, however, are rare in those areas. The information contained in the articles are valuable in terms of future planning of water resources at the national level, which may have indirect effect on near-by falaj systems.

Abdel Baqui (1995) summarized general information of soil types in Oman. Most soils in Oman have high infiltration rate and low moisture content. In general, it is reported that common natural soil needs improvement for increasing the efficiency of irrigation water. According to those authors, about $7 \%$ of Omani soils are suitable for irrigation. Out of this, $4.55 \%$ is classified as marginally suitable. Moreover, $77 \%$ of these marginally suitable soils face the problem of over salinity where the electric conductivity was found to be very high.

Table 3: Water holding capacity of soils in south Batinah region. Note that the Notations for Texture categories are standard abbreviations used by the US Department of Agriculture and are combined with the following interpretations of associated alphabets. $\mathrm{C}=$ clay, $\mathrm{F}=$ fine, $\mathrm{H}=$ heavy, $\mathrm{L}=$ loam or light, $\mathrm{SI}=$ silt, $\mathrm{S}=$ sand and $\mathrm{V}=$ very.

\begin{tabular}{|c|c|c|c|c|c|c|}
\hline \multirow[t]{2}{*}{$\begin{array}{c}\text { Texture } \\
\text { Category }\end{array}$} & \multicolumn{6}{|c|}{$\begin{array}{l}\text { Coarse Fragment Category (\% of Total coarse fragment } \\
\text { content, TCFC ) }\end{array}$} \\
\hline & $\begin{array}{c}0 \\
(>\mathrm{TCFC}<5 \%)\end{array}$ & 1 & 2 & 3 & 4 & $\begin{array}{c}5 \\
(<\mathrm{TCFC}<78 \%)\end{array}$ \\
\hline C,CL,SIC, SICL,SC & $5.3^{*}$ & 4.8 & 4.2 & 2.9 & 1.6 & 0.5 \\
\hline SCL,HL,HSIL & 4.5 & 4.1 & 3.6 & 2.5 & 1.4 & 0.5 \\
\hline SI,SIL & 5.3 & 4.7 & 4.2 & 2.9 & 1.6 & 0.8 \\
\hline $\begin{array}{l}\text { L,FSL, } \\
\text { VFSL, } \\
\text { HSL, } \\
\text { HFSL }\end{array}$ & 3.4 & 3.0 & 2.7 & 1.9 & 1.0 & 0.3 \\
\hline $\begin{array}{l}\text { SL,CSL } \\
\text { HCSL, } \\
\text { LVFS }\end{array}$ & 2.6 & 2.4 & 2.1 & 1.4 & 0.8 & 0.3 \\
\hline $\begin{array}{l}\text { LS,LFS } \\
\text { LCS } \\
\text { VFS } \\
\text { FS }\end{array}$ & 1.6 & 1.4 & 1.3 & 0.9 & 0.5 & 0.2 \\
\hline $\begin{array}{l}\mathrm{CS} * * \\
\mathrm{~S}\end{array}$ & 0.8 & 0.7 & 0.6 & 0.4 & 0.2 & 0.1 \\
\hline
\end{tabular}

*Percentage by weight; ** Coarse sand

Most soils in Oman, particularly in Batinah coast (an aflaj area) are of medium coarse textured soils consisting of sands, loamy sands and sandy loams. The depth of soil varies from 30 to $100 \mathrm{cms}$ in most areas. The organic matter containing nitrogen and phosphate is low in quantity. Limestone in mountains in Batinah region is high. Calcium carbonate in soil is about $35 \%$ in Batinah coast. However, in Batinah, the micronutrient deficiency is less. Soil pH is moderate to strong alkaline. Table 3 adopted from Aldel-Baqui (1995) and MAF (1993) shows the water holding capacities of soils in south Batinah region. Abdel-Baqui, (1995) also presented soil horizons of Oman in six categories. Table 4 adopted from Abdel-Baqui (1995) shows important ranges of land characteristics that classify the soils as suitable, marginally suitable and non-suitable for irrigation.

Abdel Magid (1995) presented the results of his study which indicated that the application of organic manure might improve the soil texture. Omanis, however, presently widely practice the method of improving the soil texture in agricultural lands by transferring deposited silt from 


\section{REVIEW OF OMANI AFLAJ SYSTEMS}

upstream dams and mixing it with top soils. Mixing of top $10 \mathrm{~cm}$ of common soils with imported silt was proven to be successful. Water application could be reduced up to $40 \%$ in cases through this type of soil treatment. The author outlined schemes of soil management in irrigation systems, which was found to be effective in saving plants from the salinity that accumulates in surrounding soils from irrigation water.

Table 4: Soil characteristics classifying irrigation suitability

\begin{tabular}{|c|c|c|c|}
\hline Land Characteristics & Suitable & $\begin{array}{l}\text { Marginally } \\
\text { Suitable }\end{array}$ & $\begin{array}{l}\text { Not } \\
\text { Suitable }\end{array}$ \\
\hline Depth to restricting layer $(\mathrm{cm})$ & $>150$ & $100-150$ & $<50$ \\
\hline $\begin{array}{l}\text { Rock fragments between depths of } 25 \\
\text { and } 100 \mathrm{~cm} \text { (Weighted by volume) }\end{array}$ & $<15$ & $15-35$ & $>65$ \\
\hline $\begin{array}{l}\text { Water retention difference to a depth } \\
\text { of } 150 \mathrm{~cm} \text { or to a restricting layer }(\mathrm{cm})\end{array}$ & $>15$ & $8-15$ & $<6$ \\
\hline $\begin{array}{l}\text { Maximum salinity within a depth of } \\
100 \mathrm{~cm} \text { (EC of paste extract in } \mathrm{ds} / \mathrm{m} \text { ) }\end{array}$ & $<8$ & $8-16$ & $>16$ \\
\hline $\begin{array}{l}\text { Gypsum content in } 0-50 \mathrm{~cm} \text { depth } \\
\text { (Vol. \%) }\end{array}$ & $<10$ & $10-25$ & $>25$ \\
\hline $\begin{array}{l}\text { Gypsum content in } 50-100 \mathrm{~cm} \text { depth } \\
\text { (Vol. \%) }\end{array}$ & $<10$ & $10-25$ & $>40$ \\
\hline Slope Gradient $(\%)$ & $<1$ & $1-3$ & $>5$ \\
\hline $\begin{array}{l}\text { Vertical hydraulic conductivity of the } \\
\text { least pervious layer within the depth } \\
\text { of } 100 \mathrm{~cm}(\mathrm{~m} / \mathrm{h})\end{array}$ & $0.5-15$ & $<0.5 . \mathrm{R}>15$ & -- \\
\hline Depth of water-table (cm) & $>300$ & $150-300$ & $<50$ \\
\hline $\begin{array}{l}\text { Expected natural drainage under } \\
\text { irrigation }\end{array}$ & Good & Moderate & V.poor \\
\hline Erosion hazard & Slight & Moderate & V. strong \\
\hline Flooding hazard & Slight & Moderate & V. strong \\
\hline
\end{tabular}

\section{Irrigated Agriculture and Water Resources}

Records indicate that in the last two decades, Oman extensively studied its groundwater resources (Al-Battushi, 1997; Bernett, 1994; MWR, 1994a; Mott MacDonald, 1991a; 1991b; Petroleum Development Oman, PDO, 1998; Mott MacDonald, 1989; WS-Atkins, 1990). Among the various programs related to water resources the Ministries of Water Resources and Agriculture and Fisheries undertook are two ambitious projects of preparing the nation's well inventory (Chandler, 1995; GIBB, 1975; MWR, 1992a; 1992b; 1992c; 1993a; 1994b) and schemes of recharging acquifer systems (Al-Akhzarni, 1997; MWR, 1993b; Mohsin, 1995; Mott MacDonald, 1991a; 1991b; 1994a; 1994b; 1994c; Travers, 1993; WS-Atkins, 1990; WS-Atkins, 1992a; WSAtkins, 1992b).

The national well inventory program was launched in 1998. The program involves gathering information about existing wells throughout the country. The information bank includes the location of a well, well identification by number, ownership, physical characteristics, quality of water (electric conductivity Ec and $\mathrm{pH}$ ), current uses, service area, water users and water demand. The program is progressing satisfactorily and is expected to cover all wells in the country in the near future. The completion of the program will clearly identify the wells of aflaj systems along with individual wells in surroundings areas. Such information is expected to directly aid the process of modern planning and management of traditional aflaj systems. 


\section{SHAHALAM}

The purpose of the recharge dams is to store the scanty rainfall water underground. Such storage is prefered for several reasons. Acquifer waters are less prone to evaporation loss. Recharge dams retard loss of fast flowing runoff into the sea. Due to Steep Mountain slope and short coastal range, most of the runoff, at the coastal side of the mountains, would be lost. One of the direct benefits felt in aflaj systems is the rise of groundwater level. This was particularly observed in the northeast mountain ridges and plains. In particular, some of the aflaj-wells in Al-Batinah and Wadi Al-Fulayj indicated a rise in well-water level and water production (Al-Battushi, 1997). This was the result of some recharge dams. As of 1996, the Sultanate of Oman has built 20 (16 recharge and 4 flood control) major dams (Al-Akhzarni, 1997). An ambitious program for constructing more dams is under consideration. In the process, about 78 potential dam sites were examined. Effects of such dams on the national water resources were systematically studied and screened for feasibility and implementation.

Parallel to the water augmentation projects, quite a number of studies were carried out to explore the efficiency of existing irrigated agriculture and to gather data on the farmers' adaptability to modern techniques of irrigation ( Al-Harthy, 1995; CORD, 1992; FAO, 1984; FAO, 1992; Johnson, 1995; Lenton, 1995; MAF, 1989; 1993; Rout, 1995; Siddeek, 1992; M. MacDonald, 1989). In Particular, these studies in the areas of aflaj systems in the north coast of the country provided valuable information about present irrigation practices. Some of these studies identified beneficial activities of public organizations that may enhance the agricultural produce of economic value. One case study indicated that about $8.5 \mathrm{Mm}^{3}$ per annum could be saved by a conversion of only 1430 hectare of surface flooding to modern irrigation system (Siddeek, 1992). The study presented in Siddeek (1992) also presented a typical distribution of crop pattern in a south Batinah farm (Table 5). The case study reported that the adaptation of modern irrigation systems and the application of differential rates of watering for different crops saved substantial amount of irrigation water.

Table 5: Typical crop distribution in a south Batinah farm

\begin{tabular}{|l|c|}
\hline Crop Type & $\begin{array}{c}\text { Percentage of total land of } \\
392 \text { acres }\end{array}$ \\
\hline Datepalm & 22.83 \\
\hline Greenhouse & 0.34 \\
\hline Citrus & 10.78 \\
\hline Mango & 2.83 \\
\hline Mixed ( Datepalm + Citrus + Mango ) & 3.45 \\
\hline Other trees spp. & 14.18 \\
\hline Ornamental + lawn & 0.74 \\
\hline Winter vegetables & 19.6 \\
\hline Summer vegetables & 1.63 \\
\hline Rhodes grass & 24.17 \\
\hline Tall grass & 0.45 \\
\hline
\end{tabular}

\section{Management and Maintenance of Aflaj Systems}

Several articles (Al-Kalbani, 1993; Bernett, 1994; De Jong, 1995; Dutton, 1985; 1995; Hundertmark, 1995; Johnson, 1995; Lenton, 1995; Ministry of Health, MH, 1992; Vermillion, 1992) covered various schemes of aflaj management in the light of the traditional ways in aflaj systems. The University of Durham (UK) studied extensively various aspects of aflaj. The results were reported with suggestions to modernize the management for the revival of aflaj systems (AlKalbani, 1993; 1985; 1995). 


\section{REVIEW OF OMANI AFLAJ SYSTEMS}

Dutton (1995) identified the inherent weaknesses and strengths of the traditional aflaj management. The author itemized the elements of management activities that fall within the jurisdiction of the Ministry of Water Resources. The items are grouped into two categories such as active and proactive management activities. The first group included issues such as responding to daily queries about well permits, falaj extension, disputes between users of aflaj mother-well protection and day-to-day problems and crises. Proactive management activities involved planned steps towards a solution and reduction of future problems related to inappropriate, unbalanced, non-equitable, inefficient, and non-productive water usages. The author focused on the inherent strength of the traditional aflaj systems in their organization and management systems at community level. He pointed out that the better quality of this organizational management might be effectively used if an effective connection could be maintained between traditional aflaj delivery systems and modern irrigation practices.

Lenton (1995) discussed in general the privatization and irrigation management transfer from public to private organization. The approach appeared to be effective in small farms in many parts of the world. The approach appeared to have potential usage in aflaj systems in Oman. Following the same topic, Vermillion (1992) and Johnson (1995) presented results of case studies involving partial management with public agencies (such as the Ministry of Water Resources) retaining management and control of water sources with the main distribution channels when the field management is trusted to the end-users. Lenton stressed the participating approach between the public organizations and end-users. In his model of farm management, the end-users jointly participate in the operation and maintenance of irrigation systems. Water users associations constituted of farmers involved in management decisions, in collecting fees to cover operation and maintenance costs and organizing maintenance activities. His approach, however, uses raw concepts. Its applicability to Omani national policy and farmers' well being needs to be tested.

De Jong and Gaubh (1995) discussed water resources management at the government organization level in countries of arid regions. The authors stressed the need for strict separation of functions among environmental protection, water resources and water management functions on the one side and the concerns of water users on the other. The authors' model of water management in arid regions such as Oman advocates sector separation by functions among various public organizations.

Rout (1995) discussed social and economic aspects of metering waters abstracted from wells in a farming area in Oman. The author cautiously noted that the success of such programs would largely be dependent on the acceptance and support of the well owners for installations, monitoring and associated conservation measures.

The revival of traditional aflaj systems in Oman and their adaptation to modern technology and management may require major work for initial system repair with follow-up attention for day-today maintenance works. A BRGM report (BRGM, 1992) prepared for the Ministry of Agriculture and Fisheries outlined in details the general items of such maintenance works in 12 aflaj systems in Oman. The report provided valuable guidelines for the maintenance works involved in Omani aflaj systems.

\section{Conclusions and Recommendations}

The following conclusions could be drawn based upon the data collected from the available literature.

1. Recharge dams appear to be a good means for better management of aflaj systems and an important element in the overall water resources management in the Sultanate of Oman.

2. Participation approach involving end-users of aflaj communities and public organizations can be an effective tool for future decisions and future planning of projects or introducing changes in the present system.

3. Aflaj systems can be linked to modern irrigation practices so that the available water is optimally utilized. 


\section{SHAHALAM}

4. Most of the Omani soils are not suitable for irrigated agriculture. The augmentation of these soils with deposited silt from upstream dams has been successful and should be continued in the future.

5. New sources of low-cost soil amendment agents should be explored. Sludge from wastewater treatment plant and decomposed products of wastes from agricultural activities, oil industries and municipal solid wastes might possess good potential for the purpose.

6. Clarity of the roles played by public organizations such as various Ministries and local institutions will clearly help optimize the falaj management system.

\section{References}

ABDEL BAQUI, ABDEL MAGID, E. 1995. Soil Management under Modern Irrigation Systems in Oman. Proceedings. Proceedings of International Conference "Water Resources Management in Arid Countries", Ministry of Water Resources, Sultanate of Oman, Muscat, March 1995. Oman.

AL-BATTUSHI, M.B. and ALI, S.A. (MINISTRY OF WATER RESOURCES, OMAN). 1997. Groundwater Recharge of Oman. Proceedings of "Third Gulf Water Conference", Muscat, March 1997. Oman.

AL-AKHZARNI, S., O'BRIEN, W. AND COOKSON, I. 1997. Screening of Recharge Dam Sites in Oman. Proceedings of "Third Gulf Water Conference", Muscat. March, 1997. Oman.

AL-HARTHY, S.S., FARBRIDGE, R.A. and WYNESS, A.J. 1995. Irrigation Development in Nejd, Southern Oman. Proceedings of "International Conference on Water Resources Management in Arid Countries", Muscat, Ministry of Water Resources, March, 1997. Muscat, Oman.

AL-KALBANI, M.K. and DUTTON, R.W. 1993. Study for the Design of an Aflaj Management Programme, CORD, University of Durham, UK.

BERNETT, J.C. and SMITH, O.V. 1994. The National Well Inventory, Sultanate of Oman. Groundwater - Drought Pollution and Management. Reeves and Watts (eds), ISBN 9054103515.

BRGM. 1992. Design of Maintenance Works for 12 Aflaj in Northern Oman. Inception Report to the Ministry of Agriculture and Fishery, Oman.

CHANDLER, M.S. and AL-ABRI, A. 1995. Quality Control and Technical Analysis - Essential Components of a Successful well Inventory. Proceedings of "International Conference on Water Resources in Arid Countries", Ministry of Water Resources, Muscat, March 1995, Oman.

CORD (John Farnworth). 1992. Guideline Discussion Paper for Use of Water of 3000 - 4000 micromhos and over with Modern Irrigation Techniques. Report submitted to Ministry of Water Resources (Oman), CORD, University of Durham.

DE JONG, R.L. and GAUBH, G.T.Z. 1995. Aridity, Economic Development, and Water Sector Management. Proceedings of "International Conference on Water Resources Management in Arid Countries", Muscat, Ministry of Water Resources, March 1995. Oman. pp. 228-234.

DUTTON, R.W. 1985. Modernizing Falaj Irrigation System - A Proposal for an interior action Research centre. University of Durham.

DUTTON, R.W. 1995. Towards a Secure Future for the Aflaj in Oman. Proceedings of "International Conference on Water Resources Management in Arid Countries", Muscat, Ministry of Water Resources, Muscat, March 1995. Oman.

FAO. 1984. Crop Water Requirements, Irrigation and Drainage Paper No. 24.

FAO. 1992. Integrated Study of Salalah Plain, Irrigation Report.

GIBB, A. and PARTNERS, ILACO, SOGREAH. 1975. Water Resources of Northern Oman (Final Report).

HUNDERTMARK, W. (GERMAN TECHNICAL COOPERATION AUTHORITY) and ALMAMARI, S. (MINISTRY OF AGRICULTURE and FISHERIES, OMAN). 1995. Efficient On-Farm Irrigation Management Under Typical Crop, Soil and Climate Conditions in Oman. 


\section{REVIEW OF OMANI AFLAJ SYSTEMS}

Proceedings of "International Conference on Water Resources in Arid Countries", Muscat, March 1995. Oman.

JOHNSON, S.H. 1995. Selected Experience with Irrigation Management Turnover: Economic Implications. Special IIMI Issue, Water Resources Development.

KEW, G.A.1995. Irrigation in Central Oman.1995. Proceedings of "International Conference on Water Resources Management in Arid Countries", Muscat, Ministry of Water Resources, March 1995. Oman.

LENTON, R. 1995. Efficient Water Use in Agriculture: Recent Findings and New Innovations. Proceedings of "International Conference on Water Resources Management in Arid Countries", Muscat, Ministry of Water Resources, March 1995. Oman.

LONDON, J.R., 1984. Booker Tropical Soil Manual, Booker Agricultural International Ltd.

MINISTRY OF AGRICULTURE and FISHERIES (MAF), OMAN. 1989. Pilot Project for Agriculture Development - Jubrin and Jimah.

MINISTRY OF AGRICULTURE and FISHERIES (MAF), OMAN and FAO. 1990. General Soil Map of the Sultanate of Oman.

MINISTRY OF AGRICULTURE and FISHERIES (MAF), OMAN and FAO. 1993. South Batinah Integrated Study Report.

MINISTRY OF HEALTH (MH), OMAN. 1992. A Proposal for a Community-Based InterMinisterial Sustainable Rural Development Project with emphasis on Water Supply and Sanitation.

MINISTRY OF INFORMATION (MI), OMAN. 1997. Publication.

MINISTRY OF WATER RESOURCES (MWR), OMAN. 1991. Water Resources of the Sultanate of Oman - An Introductory Guide.

MINISTRY OF WATER RESOURCES (MWR), OMAN. 1992a. National Water Resources Master Plan: Volume 1 -Executive Summary. Prepared by Mott- McDonald International Ltd. UK.

MINISTRY OF WATER RESOURCES (MWR), OMAN. 1992b. National Water Resources Master Plan: Volume 2 - Main Report. Prepared by Mott-McDonald International Ltd. UK.

MINISTRY OF WATER RESOURCES (MWR), OMAN. 1992c. The National Well Inventory Project. Report to HE the Minister.

MINISTRY OF WATER RESOURCES (MWR), OMAN. 1993a. Inventory Operations Manual, First Edition, National Well Inventory.

MINISTRY OF WATER RESOURCES (MWR), OMAN. 1993b. Wadi Dayqah Hydrotechnical Study Report.

MINISTRY OF WATER RESOURCES (MWR), OMAN. 1994a. Technical Catchment Report Salalah-Taqah Plain and Adjacent Catchments. Internal Report, National Well Inventory.

MINISTRY OF WATER RESOURCES (MWR), OMAN. 1994b. The National Well Inventory Project. Catchment Technical Report, Wadi Taww.

MINISTRY OF WATER RESOURCES (MWR), OMAN. 1995. Water Resources of the Sultanate of Oman - An Introductory Guide.

MINISTRY OF NATIONAL ECONOMICS (MNE), OMAN. 1999. Monthly Statistical Bulletin. V. 10, No. 9. Ministry of Economics, Oman.

MOHSIN, A., O'BRIEN, W. and BRADFORD, M. 1995. Hydrotechnical Feasibility of Recharge Dams in Eight Interior Catchments of Oman. Proceedings of "International Conference on Water Resources Management in Arid Countries", Muscat, Ministry of Water Resources, March 1995. Oman.

MOTT MACDONALD INTERNATIONAL. 1991a. Groundwater Recharge Schemes for AlKhaburah area. Report submitted to the Ministry of Agriculture and Fisheries. Muscat, Oman.

MOTT MACDONALD INTERNATIONAL. 1991b. Groundwater Recharge Schemes for Saham Sohar area. Report submitted to the Ministry of Agriculture and Fisheries. Muscat, Oman.

MOTT MACDONALD INTERNATIONAL. 1994a. Detailed Hydrotechnical Recharge Studies in Dhahira - Wadi Al Aridh. Report submitted to the Ministry of Water Resources. Muscat, Oman. 


\section{SHAHALAM}

MOTT MACDONALD INTERNATIONAL. 1994b. Detailed Hydrotechnical Recharge Studies in Dhahira - Wadi Yanqul. Report submitted to the Ministry of Water Resources. Muscat, Oman.

MOTT MACDONALD INTERNATIONAL. 1994c. Detailed Hydrotechnical Recharge Studies in Dhahira - Wadi Kabir and Wadi Lusayl (Al Asil). Report submitted to the Ministry of Water Resources. Muscat, Oman.

NORMAN, W.R., SHAYYA, W.H., AL-GHAFRI, A.S. and MCCANN, I.R. 1997. Aflaj Irrigation Water Management and Efficiencies: A Case Study from Northern Oman. Proceedings of "Third Gulf Water Conference", Muscat, March 1997. Oman.

PETROLEUM DEVELOPMENT OMAN, OMAN (PDO). 1988. The Desert Agricultural Project. A Report on Project Development. PDO. Oman.

ROUT, R.S. (MINISTRY OF WATER RESOURCES, OMAN). 1995. Social and Economical Aspects of Water Metering in the Sultanate of Oman. Proceedings of "International Conference on Water Resources Management in Arid Countries", Muscat, Ministry of Water Resources. March 1995. Oman.

SIDDEEK, Z.M. AL-LAWATIA. 1992. Evapotranspiration and Crop Water Requirements. Report Submitted to Ministry of Water Resources, Oman (Unpublished).

SIR M. MACDONALD and PARTNERS. 1989. Groundwater Recharge Schemes for Barka-Rumais area. Report submitted to the Ministry of Agriculture and Fisheries. Muscat, Oman.

STATE CONSULTATIVE COUNCIL (SCC), OMAN. 1987. The State Consultative Council Recommendations about the Study of the Effects on the Aflaj and their Flowing Feeder Branches from Existing Wells near their Mother Wells. Report prepared by Office of the President of SSC.

TRAVERS MORGAN (OMAN) LTD. 1993. Detailed Hydrotechnical Recharge Studies in Wadi AlGhulaji. Report submitted to the Ministry of Water Resources. Muscat, Oman.

TROW (OMAN) LTD. 1986. Soil Profiles and Infiltration Rates - Wasit. Report submitted to Public Authority for Water Resources. Muscat, Oman.

WAHBY, H. and AL-HARTHY, S.S., 1995. Central Controlled Irrigation System for Optimum use of Water in Falaj Keed at Bahla, Oman Interior. Proceedings of "International Conference on Water Resources Management in Arid Countries", Muscat, Ministry of Water Resources. March 1995. Oman.

WILKINSON, J. 1977. Water and Tribal Settlement in South East Arabia. Oxford Research Studies in Geography. Clarendon Press.UK.

WILKINSON, J.C. 1983. The Origin of the Aflaj of Oman. J. of Oman Studies, 6: 177-194.

WS ATKINS INTERNATIONAL. 1990. Groundwater Recharge Schemes for Ibri/Araqi area. Report submitted to the Ministry of Agriculture and Fisheries, Muscat, Oman.

WS ATKINS INTERNATIONAL. 1992a. Detailed Technical Studies for Proposed Recharge Facilities in Wadi Muaydin. Report submitted to the Ministry of Water Resources. Muscat, Oman.

WS ATKINS INTERNATIONAL. 1992b. Detailed Technical Studies for Proposed Recharge Facilities in Wadi Halfayn. Report submitted to the Ministry of Water Resources. Muscat, Oman.

VERMILLION, D.L. 1992. Irrigation Management Turnover; Structural Adjustment or Strategic Evaluation. IIMI Review. 6(2): 3-12.

Received 1 January 2000

Accepted 25 June 2001 